\title{
Probiotic and Prebiotic Utilization in Diets for Free-Range Broiler Chickens*
}

\section{Author(s)}

Pelícia $K^{1}$

Mendes $\mathrm{AA}^{2}$

Saldanha ESPB ${ }^{3}$

Pizzolante $\mathrm{CC}^{3}$

Takahashi SE ${ }^{1}$

Garcia RG

Moreira $J^{1}$

Paz ICLA'

Quinteiro RR

Komiyama $\mathrm{CM}^{1}$

Graduate student, Veterinary Medicine and Animal Science College, UNESP, Botucatu, São Paulo State, Brazil.

2 Full-professor of Animal Production and Science Department, Veterinary Medicine and Animal Science College, UNESP, Botucatu, São Paulo State, Brazil.

3 Scientist of Agência Paulista de Tecnologia dos Agronegocios de Brotas, São Paulo State, Brazil.

\section{Mail Address}

Kleber Pelícia

UNESP - Universidade Estadual Paulista

Faculdade de Medicina Veterinária e Zootecnia

Câmpus de Botucatu

Fazenda Experimental Lageado, s/n

18.618-000 - Botucatu, SP

Fone: 551438825735

E-mail: fokleber@fca.unesp.br

\section{Keywords}

Breeding system, growth promoter, intestine, Label Rouge, symbiotic.

Research support by EMBRAPA (Empresa Brasileira de Pesquisa Agropecuária Concórdia, SC).

From master thesis of the first author. Veterinary Medicine and Animal Science College, UNESP, Botucatu, São Paulo State, Brazil.

\section{ABSTRACT}

This work aimed to evaluate the effects of probiotic associated to prebiotic on performance, carcass and cut yields, qualitative traits of meat, development and score of lesions due to coccidiosis in digestive tract of broiler chickens raised in a free-range system during 85 days. One thousand, six hundred and ninety-six day-old male broiler chicks from naked-neck ISA S757-N Label Rouge line were used in a randomized block design with factorial scheme of $4 \times 2$ and four repetitions. The effect of four additive (1 - biologic promoter + coccidiosis vaccine; 2 biologic promoter + anti-coccidiosis; 3 - chemical promoter + coccidiosis vaccine; 4 - chemical promoter + anti-coccidiosis) and two breeding systems from $35^{\text {th }}$ day of age (one with no-access to pasture or confined and the other with free-access to pasture or semi-confined) on performance parameters, carcass and cut yields, qualitative meat traits, coccidiosis development and lesions in digestive tract were evaluated. There was effect $(p<0.05)$ of additives only on sensorial analysis (meat quality) and percentage of large intestine. Breeding systems affected $(p<0.05)$ live weight $(L W)$ and $L W$ gains, being the better results observed in semi-confined birds.

\section{INTRODUCTION}

Normative instruction $n^{\circ}$ 007, published in May 17, 1999 by Agriculture and Supply State Department (Brasil, 1999), and Report MA n 505, from October 16, 1998, established the criteria for agro-ecological production in Brazil. In complement, the Official Circular Letter $n^{\circ} 007$, from May 19, 1999 (Brasil, 1999), normalized free-range chicken production. Lines must be specific and birds must be raised in chicken houses until 28 days of age. After, they must have free access to pastures with at least $3 \mathrm{~m}^{2}$ per bird. Feeding must be made with non-animal ingredients, non-chemical promoters and breeding period must have at least 85 days.

Since them, free-range broiler chicken production has been increasing in Brazil due to its low initial investment and an alternative for small farmers. Besides, there are consumers that prefer meat from birds raised in nature. This kind of producers is common in Europe, where the broiler chickens has access to pasture, the so-called free-range systems, and have been transformed in a very important economical activity (Cothenet, 1998).

However, this kind of system requires some handling and feeding adaptations, mainly in relation to additive utilization. So, an alternative for replacing chemical promoter might be the use of probiotic associated to probiotic and coccidiosis vaccine instead of anti-coccidiosis.

This study was carried out aiming to evaluate the utilization of probiotic associated to prebiotic and coccidiosis vaccine on performance 
Pelícia K, Mendes AA, Saldanha

ESPB, Pizzolante CC, Takahashi SE,

Garcia RG, Moreira J, Paz ICLA,

Quinteiro RR, Komiyama CM
Probiotic and Prebiotic Utilization in Diets for Free-Range Broiler Chickens* parameters, carcass and cut yields, meat qualitative traits and lesions scores caused by coccidiosis in digestive tract of broiler colonial chickens raised in freerange conditions.

\section{MATERIAL AND METHODS}

The experiment was carried out in the facilities of Agência Paulista de Tecnologia dos Agronegócios, Brotas City, São Paulo State, Brazil, during 85 days. One thousand, six hundred and ninety-six one-day-old male broiler chicks from naked neck ISA S757-N Label Rouge line were used in a randomized block design experiment arranged in a $4 \times 2$ factorial schedule. The effect of four additive groups (1 - biologic promoter + coccidiosis vaccine; 2 - biologic promoter + anticoccidiosis; 3 - chemical promoter + coccidiosis vaccine; 4 - chemical promoter + anti- coccidiosis) and two breeding systems (one with no-access to pasture or confinement and the other with free-access to pasture or semi-confinement) were evaluated with four repetitions per treatment. Pasture of Brachiaria decumbens was used and according Brazilian legislation the area was $3 \mathrm{~m}^{2}$ per bird. Birds from semi-confinement system had access to pasture from $35^{\text {th }}$ of age. Percentual and calculated compositions of ingredients in the diets offered per breeding phase are shown in Table 1. Nutritional levels were those recommended by Embrapa for colonial broiler chickens with modifications (Embrapa, 2004). In Table 2 are shown the group of additives used according to breeding phases. Ration were prepared with ground ingredients and mixed at food facilities.

Birds were weighted and distributed among treatment. The following parameters were evaluated: weight gain, feed intake and feed conversion at $28^{\text {th }}$, $63^{\text {rd }}, 77^{\text {th }}$ and $84^{\text {th }}$ of age. Feed conversion in confinement and semi-confinement was calculated dividing total feed intake by total live weight plus weight of dead birds.

After 12 hours of fasting, slaughter and intestine evaluation were done at 85 days of age. Small and large intestines were separated for individual length measuring and weighting. Carcass yield, cuts (breast, meat breast, legs, leg meat, wings and back), abdominal fat and quantitative analysis of meat (length, width, and height of breast meat, $\mathrm{pH}$ of breast meat and leg, weight loss by cooking and shearing force of breast meat) were evaluated. Carcass yield, abdominal fat and intestine were calculated using the formula: $[\% Y=($ Weight of the specific portion*100)/
Live Weight]. For calculation of cuts yields, the formula was: [\% Y cut $=($ Weight of the specific cut* 100$) / C$ arcass weight]. The meat $\mathrm{pH}$ was measured by inserting an electrode directly on breast and leg muscles 24 hours post mortem. For breast physical determinations, pectoralis major was dissected, weighted and measured in relation to length, width and height. These measurements were done using a caliper, being the height measured at the thicker part of muscle. For estimating weight loss by cooking, the left steak of each breast was taken, weighted, packaged in aluminum paper and cooked. After cooking, it was weighted again and the weight difference between cooked and raw steak was considered the cooking loss. Shearing force was measured in these same muscles samples using a Warner-Bratzler equipment.

\begin{tabular}{|c|c|c|c|}
\hline \multirow[t]{2}{*}{ Ingredients } & \multicolumn{3}{|c|}{ Phases (days) } \\
\hline & $1-28$ & $29-63$ & $64-84$ \\
\hline Corn & 61.117 & 66.770 & 73.020 \\
\hline Soybean meal & 34.547 & 29.084 & 23.494 \\
\hline Bicalcium phosphate & 1.869 & 1.738 & 1.497 \\
\hline Calcitic Calcarium & 1.062 & 1.187 & 1.254 \\
\hline Soybean oil & 0.763 & 0.572 & 0.100 \\
\hline Sodium chloride & 0.350 & 0.350 & 0.350 \\
\hline Methionine & 0.093 & 0.099 & 0.084 \\
\hline MethVitamin supplement ${ }^{1}$ & 0.100 & 0.100 & 0.100 \\
\hline Mineral supplement ${ }^{2}$ & 0.100 & 0.100 & 0.100 \\
\hline Total & 100.00 & 100.00 & 100.00 \\
\hline \multicolumn{4}{|c|}{ Calculated nutrient composition } \\
\hline Metabolizable energy $\mathrm{Kcal} / \mathrm{kg}$ & 2,900 & 2,950 & 3,000 \\
\hline Crude Protein & 21.0 & 19.0 & 17.0 \\
\hline Calcium & 1.00 & 1.00 & 0.95 \\
\hline Available Phosphorus & 0.46 & 0.43 & 0.38 \\
\hline Lisine & 1.05 & 0.93 & 0.80 \\
\hline Methionine & 0.42 & 0.40 & 0.36 \\
\hline Methionine + Cisteine & 0.735 & 0.685 & 0.618 \\
\hline \multicolumn{4}{|c|}{ 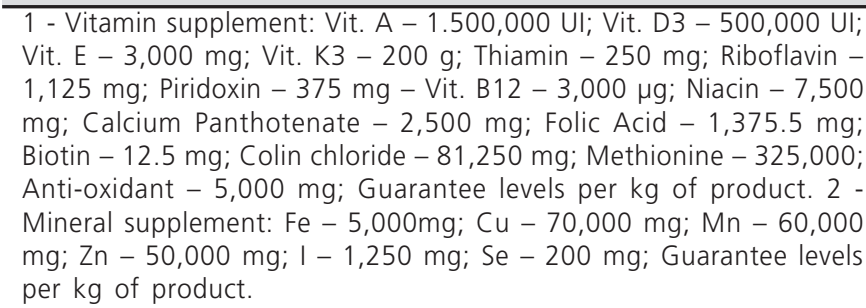 } \\
\hline
\end{tabular}

Samples for sensorial analysis were without salt and packaged in aluminum paper for heating until $200^{\circ} \mathrm{C}$ in an electric surface with double resistance, during 6 minutes, being revolved every three minute and their internal final temperature was around $85^{\circ} \mathrm{C}$. The samples were placed in Petri plates, heated until 45 or $50^{\circ} \mathrm{C}$ in microwave per 25 seconds and offered to tasters. This test was done by a panel of 40 tasters in 
Pelícia K, Mendes AA, Saldanha ESPB, Pizzolante CC, Takahashi SE, Garcia RG, Moreira J, Paz ICLA, Quinteiro RR, Komiyama CM Broiler Chickens* individual cabins under red light. Also, consumer preference was tested using a linear non-structured scale from 0 to 10 points for the parameters of softness, taste and global impression, where zero corresponded to a sample with a hard consistence, non-characteristic taste and few acceptable, and ten corresponded to a sample very soft, with a very characteristic taste and very acceptable.

Table $\mathbf{2}$ - Additives used in the experimental diets of colonial broiler chickens at different phases of breeding.

\begin{tabular}{|c|c|c|c|c|}
\hline \multirow{2}{*}{ Additives } & \multicolumn{4}{|c|}{ Phases (days) } \\
\hline & $1-28$ & $29-63$ & $64-77$ & $78-84$ \\
\hline \multicolumn{5}{|c|}{ Chemical Promoters } \\
\hline Virgimicin 50\% (10 ppm) & 20 g.ton ${ }^{-1}$ & - & - & - \\
\hline Olaquidox 99\% (50 ppm) & 50 g.ton ${ }^{-1}$ & - & - & - \\
\hline Olaquidox 99\% (30 ppm) & -3 & 30 g.ton ${ }^{-1}$ & 30 g.ton ${ }^{-1}$ & - \\
\hline \multicolumn{5}{|c|}{ Biological Promoters } \\
\hline "Colostrum Avis ${ }^{\circledR 11}$ & $2 \mathrm{~g}$ per bird & & & \\
\hline probiotic + prebiotic & at $1^{\text {st }}$ day & - & - & - \\
\hline $\begin{array}{l}\text { "Symbiotic Plus }{ }^{\circledR " *} \\
\text { prebiotic }+ \text { prebiotic }\end{array}$ & $\begin{array}{l}2 \mathrm{~kg} . \\
\text { ton }^{-1}\end{array}$ & $\begin{array}{l}2 \mathrm{~kg} \\
\text { ton-1 }^{-1}\end{array}$ & $\begin{array}{l}2 \mathrm{~kg} . \\
\text { ton }^{-1}\end{array}$ & - \\
\hline \multicolumn{5}{|c|}{ Anti-coccidiosis } \\
\hline Nicarbazin 25\% (50ppm) & 200 g.ton ${ }^{-1}$ & & - & - \\
\hline Monensin 20\% (60 ppm) & 300 g.ton ${ }^{-1}$ & $1-$ & - & - \\
\hline Salinomicin $12 \%(60 \mathrm{ppm})$ & -5 & 500 g.ton & 500 g.ton ${ }^{-1}$ & - \\
\hline \multicolumn{5}{|c|}{ Coccidiosis Vaccine } \\
\hline Coccivac-B & $\begin{array}{l}\text { dose per bi } \\
\text { at } 1^{\text {st }} d a y\end{array}$ & ird & - & - \\
\hline
\end{tabular}

Lesion caused by coccidiosis in duodenum, jejunum, ileum and cecum were evaluated according to lesion score from 0 to 5 points $(0$ - no lesion; 1 and 2 - very few lesions; 3 - few lesions; 4 - regular lesions and 5 lesions).

Statistic analysis were done using GLM proccedings of SAS (2000), and means were compared by Tukey test at $5 \%$ of probability.

\section{RESULTS AND DISCUSSION}

Mean, minimum and maximum temperatures during experimental period were $24.4^{\circ} \mathrm{C} \pm 0.1,22.0^{\circ} \mathrm{C} \pm 0.1$ and $29.8^{\circ} \mathrm{C} \pm 0.2$, respectively.

Since there was no interaction between groups of additives and breeding system, these both factors were individually analyzed.

In the period from 1 to 84 days (Table 3 ), additive groups did not affect bird performance, but the efficiency of the additive seems to be dependent of amount and quality of the microorganism used in probiotic production as suggested by Tournt (1998).
Birds in confinement system showed higher $(p<0.05)$ live weight and better weight gain as compared to birds of semi-confinement, findings that are contrary to those reported from Takahashi (2003).

Authors have reported that $\mathrm{Na}$ gene improve resistance of birds (Mérat, 1990; Cahaner et al., 1987); thus, the findings of this study in which low mortality was found could related with the presence of this gene in the naked neck chickens.

\begin{tabular}{|c|c|c|c|c|c|}
\hline Variables & $\begin{array}{l}\text { LW } \\
(g)\end{array}$ & $\begin{array}{l}\text { LW } \\
\text { gain } \\
\text { (g) }\end{array}$ & $\begin{array}{c}\text { Feed } \\
\text { intake } \\
(g)\end{array}$ & $\begin{array}{c}\text { Feed } \\
\text { conversion }\end{array}$ & $\begin{array}{l}\text { Mort. } \\
(\%)\end{array}$ \\
\hline \multicolumn{6}{|c|}{ Additives } \\
\hline Group $1^{2}$ & 2330 & 2289 & 6466 & 2.82 & 1.50 \\
\hline Group 2 & 2331 & 2290 & 6267 & 2.74 & 0.64 \\
\hline Group 3 & 2389 & 2348 & 6536 & 2.78 & 0.88 \\
\hline Group 4 & 2367 & $\begin{array}{l}2326 \\
\text { System }\end{array}$ & 6456 & 2.78 & 1.25 \\
\hline Confinement & $2381 a^{1}$ & $2340 a$ & 6538 & 2.79 & 1.49 \\
\hline Semi-confinement & $2327 b$ & $2287 \mathrm{~b}$ & 6324 & 2.77 & 1.15 \\
\hline$C V(\%)^{3}$ & 2.35 & 2.42 & 4.80 & 3.71 & 136.35 \\
\hline \multicolumn{6}{|c|}{$\begin{array}{l}1 \text { - Mean followed by the same letter within column are similar by } \\
\text { Tukey test }(p<0.05) 2 \text { - Group 1: biological promoter + coccidiosis } \\
\text { vaccine; Group 2: biological promoter + anti-coccidiosis; Group 3: } \\
\text { chemical promoter + coccidiosis vaccine; Group 4: chemical promoter } \\
+ \text { anti-coccidiosis. } 3 \text { - Coefficient of variation. }\end{array}$} \\
\hline
\end{tabular}

The different groups of additives in the diets did not affect ( $p>0.05$ ) yield of carcass, cuts and abdominal fat of birds (Table 4). These results are similar to those found by Sartori et al. (2003), Gonçalves et al. (2002), Maiorka et al. (2001), Loddi (1998), Owings et al. (1990) and Merkley (1985). Anyway, Moreira et al. (2001) reported differences in breast yield, which was higher in birds supplemented with chemical promoter. Jin et al. (1998) in their study reported lower fat deposition in birds treated with probiotic, suggesting that this product could interfere in the availability of fat for lipogenesis in the birds. Breeding system did not affect ( $p>0.05$ ) carcass yield, cuts and abdominal fat, corroborating the findings of Sartori et al. (2003).

Additives in diet affected meat quality, especially sensorial analysis (Table 5). Diet supplemented with biologic promoter associated to anti-coccidiosis resulted in meat with higher global impression score $(p<0.05)$ when it was compared to diet with chemical promoter associated to anti-coccidiosis. In relation to meat taste, groups of additives with biologic promoter were different among themselves; when associated to anti- 
Pelícia K, Mendes AA, Saldanha ESPB, Pizzolante CC, Takahashi SE, Garcia RG, Moreira J, Paz ICLA, Quinteiro RR, Komiyama CM
Probiotic and Prebiotic Utilization in Diets for Free-Range Broiler Chickens*

Table 4 - Live weight (g), yields (\%) of carcass, breast, leg and abdominal fat of colonial broiler chickens raised in confinement or semiconfinement and fed diets with different additives from 1 to 84 days of age.

\begin{tabular}{|c|c|c|c|c|c|c|c|}
\hline \multirow[t]{2}{*}{ Variables } & \multicolumn{4}{|c|}{ Additives } & \multicolumn{2}{|c|}{ System } & \multirow[t]{2}{*}{ CV $(\%)^{3}$} \\
\hline & Group $1^{2}$ & Group 2 & Group 3 & Group 4 & Conf. & Semi-conf. & \\
\hline Live Weight (g) & 2223 & 2249 & 2241 & 2269 & $2273 a^{1}$ & $2218 b$ & 2.33 \\
\hline Carcass (\%) & 70.17 & 70.93 & 70.63 & 70.50 & 70.16 & 70.95 & 1.95 \\
\hline Breast (\%) & 29.78 & 30.16 & 29.54 & 30.10 & 29.85 & 29.94 & 2.25 \\
\hline $\operatorname{Leg}(\%)$ & 33.43 & 33.60 & 33.40 & 33.38 & 33.48 & 33.44 & 2.28 \\
\hline Breast meat(\%) & 21.19 & 21.51 & 21.27 & 21.56 & 21.31 & 21.45 & 2.99 \\
\hline Leg meat (\%) & 22.03 & 22.27 & 22.02 & 22.50 & 22.28 & 22.14 & 3.69 \\
\hline Back $(\%)$ & 23.23 & 23.02 & 23.44 & 22.89 & 23.27 & 23.02 & 3.69 \\
\hline Wings (\%) & 12.45 & 12.64 & 12.60 & 12.32 & 12.50 & 12.51 & 2.52 \\
\hline Abdominal fat (\%) & 2.44 & 2.26 & 2.30 & 2.38 & 2.42 & 2.27 & 14.78 \\
\hline
\end{tabular}

1- Mean followed by the same letter within line are similar by Tukey test $(p<0.05)$. 2 - Group 1: biological promoter + coccidiosis vaccine; Group 2: biological promoter + anti-coccidiosis; Group 3: chemical promoter + coccidiosis vaccine; Group 4: chemical promoter + anti-coccidiosis. 3 - Coefficient of variation.

coccidiosis, they provoked meat with higher score $(p<0.05)$ in relation to those associated to coccidiosis vaccine.

Considering meat softness, there were differences among groups of additives with chemical promoter, being that associated to coccidiosis vaccine responsible by meat with higher score $(p<0.05)$ than that associated to anti-coccidiosis. The other qualitative parameters (Table 5 ) were not affected ( $p>0.05)$ by additives. Also, breeding system did not affect ( $p>0.05$ ) meat quality.

In Table 6 and Figure 1 are shown results of performance and score of lesion due to coccidiosis in digestive tract, respectively. Percentage of small intestine and length of small and large intestine (Table 6) were not affected by additives. But, in relation to percentage of large intestine, were observed differences $(p<0.05)$ among groups of additive. Anticoccidiosis associated to biologic promoter induced large intestine development and when it was associated to chemical promoter the effect was the opposite. Other authors showed differences between chemical and biological promoters also in relation to small intestine development, with heavier small intestine in birds fed diets with biological additives (Fethiere \& Miles, 1987).

In relation to coccidiosis lesions, diet with chemical promoter and anti-coccidiosis caused higher lesions in duodenum (Figure 1). Owings et al. (1990) found more lesions by coccidiosis in jejunum, with fewer incidences in birds fed diets with chemical additives. In this study similar findings were found, being observed higher lesion in jejunum than in duodenum and smaller lesions were related to diets supplemented with chemical promoter and coccidiosis vaccine.

Table 5 - Length, width and height of breast meat $(\mathrm{cm})$, breast meat $\mathrm{pH}$, leg meat $\mathrm{pH}$, weight loss by cooking ( $\mathrm{g}$ ) of breast meat (WLBM), shearing force $\left(\mathrm{kgf}_{\mathrm{kg}}{ }^{-1}\right)$ and sensorial analysis (taste, softness and global impression) of colonial broiler chicken raised in confinement or semi-confinement with diets supplemented with different additives from 1 to 84 days of age.

\begin{tabular}{|c|c|c|c|c|c|c|c|}
\hline \multirow[t]{2}{*}{ Variables } & \multicolumn{4}{|c|}{ Additives } & \multicolumn{2}{|c|}{ System } & \multirow[t]{2}{*}{ CV $(\%)^{3}$} \\
\hline & Group $1^{2}$ & Group 2 & Group 3 & Group 4 & Conf. & Semi-conf. & \\
\hline Breast length $(\mathrm{cm})$ & 17.09 & 17.12 & 17.16 & 17.21 & 17.25 & 17.04 & 2.36 \\
\hline Breast width $(\mathrm{cm})$ & 12.56 & 12.90 & 12.84 & 12.95 & 12.69 & 12.93 & 3.60 \\
\hline Breast height (cm) & 1.54 & 1.50 & 1.50 & 1.54 & 1.50 & 1.49 & 4.44 \\
\hline Breast meat pH & 5.97 & 5.99 & 6.00 & 6.00 & 5.98 & 5.99 & 0.70 \\
\hline Leg meat $\mathrm{pH}$ & 6.09 & 6.14 & 6.12 & 6.10 & 6.13 & 6.09 & 0.92 \\
\hline WLBM $(g)$ & 20.24 & 21.49 & 20.97 & 21.18 & 20.74 & 21.19 & 11.63 \\
\hline Shearing force $(\mathrm{kgf} / \mathrm{kg})$ & 2.92 & 3.31 & 3.07 & 3.06 & 3.01 & 3.18 & 11.39 \\
\hline \multicolumn{8}{|l|}{ Sensorial Analysis } \\
\hline Taste & $4.69 b^{1}$ & $5.82 a$ & $5.34 \mathrm{ab}$ & $4.94 a b$ & - - & -- & 31.03 \\
\hline Softness & $5.35 \mathrm{ab}$ & $5.68 a b$ & $6.10 \mathrm{a}$ & $5.00 \mathrm{~b}$ & --- & -1 & 30.51 \\
\hline Global Impression & $4.92 \mathrm{ab}$ & $5.87 \mathrm{a}$ & $5.68 \mathrm{ab}$ & $4.90 \mathrm{~b}$ & - - & - & 31.30 \\
\hline
\end{tabular}


Pelícia K, Mendes AA, Saldanha ESPB, Pizzolante CC, Takahashi SE, Garcia RG, Moreira J, Paz ICLA, Quinteiro RR, Komiyama CM
Probiotic and Prebiotic Utilization in Diets for Free-Range Broiler Chickens*

Table 6 - Intestine development of colonial broiler chicken raised in confinement or semi-confinement with diets supplemented with different additives from 1 to 84 days of age.

\begin{tabular}{|c|c|c|c|c|}
\hline \multirow[t]{2}{*}{ Variable } & \multicolumn{2}{|c|}{ Small Intestine } & \multicolumn{2}{|c|}{ Large Intestine } \\
\hline & Length $(\mathrm{cm})$ & Percentage (\%) & Length (cm) & Percentage (\%) \\
\hline \multicolumn{5}{|c|}{ Additives } \\
\hline Group $1^{2}$ & 117.08 & 1.80 & 37.75 & $0.55 a b^{1}$ \\
\hline Group 2 & 122.50 & 1.63 & 39.21 & 0.57 a \\
\hline Group 3 & 120.88 & 1.84 & 37.17 & $0.52 \mathrm{ab}$ \\
\hline \multicolumn{5}{|c|}{ System } \\
\hline Confinement & 118.19 & 1.69 & 38.40 & 0.55 \\
\hline Semi-Confinement & 117.75 & 1.74 & 36.56 & 0.53 \\
\hline $\mathrm{CV}^{3}(\%)$ & 6.58 & 11.29 & 7.59 & 12.74 \\
\hline
\end{tabular}
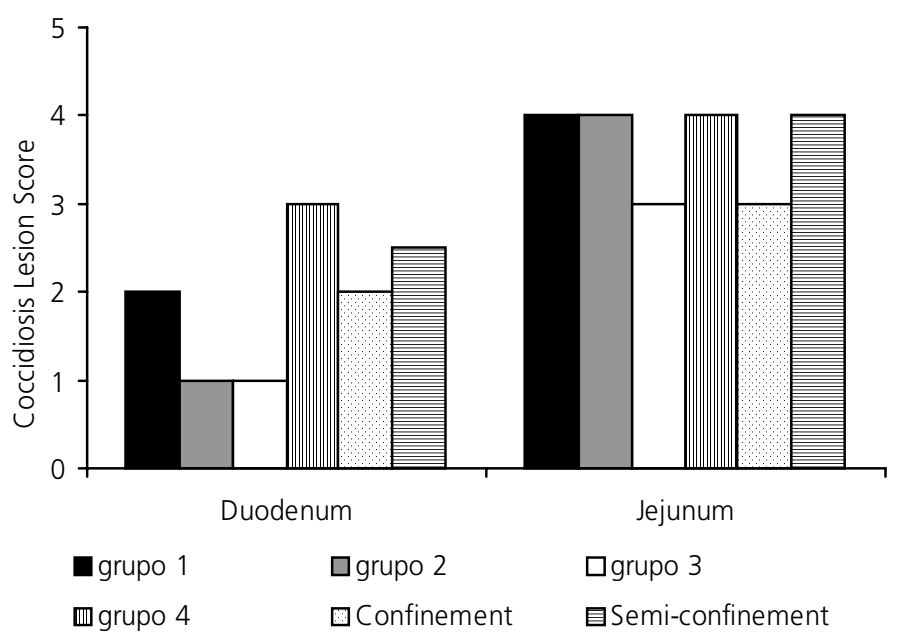

\begin{abstract}
Figure 1 - Score of coccidiosis lesions in digestive tract. Coccidiosis lesion score: where 0 is not considered, 1 and 2 are very few, 3 is few, 4 is regular and 5 is considered; Group 1: biologic promoter + coccidiosis vaccine; Group 2: biologic promoter + anticoccidiosis; Group 3: chemical promoter + coccidiosis vaccine; Group 4: chemical promoter + anti-coccidiosis.
\end{abstract}

\section{CONCLUSIONS}

Breeding system and different growth promoter resulted in coccidiosis lesion score in digestive tract below that considered harmful to birds.

Substitution of chemical by biological promoters did not affect performance, carcass and cut yields, and meat quality traits, such as length, width and height of breast meat, pH of leg and breast meat, weight loss by cooking and shearing force of breast meat.

Confinement system provoked better bird live weight and live weight gain, but semi-confinement should be an adequate alternative since it was responsible by good indexes of feed conversion, mortality rate, quality and yield of meat; and it did not affect the incidence of lesions in digestive tract due to coccidiosis, besides it proportionate better environmental comfort.

Also, it is possible to use biological growth promoter in diets for colonial broiler chickens because it was efficient for controlling coccidiosis lesion in digestive tract, besides to provide good performance indexes and meat yield and quality.

Considering breeding system, higher incidence of lesions in jejunum was observed in birds from semiconfinement than those from confinement system. In ileum and cecum no lesions were found, but Owings et al. (1990) observed higher coccidiosis lesion in ileum and cecum than in jejunum and duodenum.

\section{REFERENCES}

Brasil. Ministério da Agricultura e do Abastecimento. Ofício Circular DOI/DIPOA N007/99, de 19 de maio de 1999. Brasília, DF.

Cahaner A, Dunnington EA, Jones DE. Evaluation of two commercial broiler male lines differing in efficiency of feed utilization. Poultry Science 1987; 66(7):1101-10.

Cothenet G. A produção de frango de corte Label Rouge na França e sua atratividade. Sindicato Nacional dos Label Avícolas Franceses; 1998. Não paginado (Apostila).

Embrapa. Exigências nutricionais sugeridas para frangos coloniais, por fase de criação. In: Reunião Anual da Sociedade Brasileira de Zootecnia; 2004; Campo Grande, Mato Grosso. Brasil. 1 CD ROM.

Fethiere R, Miles RD. Intestinal tract weight of chicks fed an antibiotic and probiotic. Nutrition Reports International 1987; 36(6):130509. 
Pelícia K, Mendes AA, Saldanha

ESPB, Pizzolante CC, Takahashi SE,

Garcia RG, Moreira J, Paz ICLA,

Quinteiro RR, Komiyama CM
Probiotic and Prebiotic Utilization in Diets for Free-Range

Broiler Chickens*

Gonçalves JC, Andrade JC, Sartori JR, Martinez KLA., Pezzato AC, Costa C. Rendimento de carcaça e partes de frangos de corte alimentados com silagem de grãos úmidos de milho e simbiótico. Revista Brasileira de Ciência Avícola 2002; 4(Supplement 4):27.

Jin LZ, Ho YW, Abdullah N. Growth performance, intestinal microbial populations, and serum cholesterol of broilers fed diets containing Lactobacillus cultures. Poultry Science 1998; 77(9):1259-65.

Loddi MM. Aspectos produtivos e qualitativos do uso de probiótico para frangos de corte. [Disertação].Botucatu (SP). Universidade Estadual Paulista.1998, 60p.

Maiorka A, Santin E, Sugeta SM, Almeida JG, Macari M. Utilização de prebiótico, probiótico ou simbiótico em dietas para frangos. Revista Brasileira de Ciência Avícola 2001; 3(1):75-82.

Merat P. Pleiotropic and associated effects of major genes. Poultry Breeding and Genetics 1990; p.429-67.

Merkely JW. Probiotic supplementation of broiler and RTC carcass yields. Poultry Science 1985; 64 (Suppl. 1):145 (Abstract.).

Moreira J, Mendes AA, Garcia EA. Efeito do uso de probiótico sobre o desempenho e rendimento de carcaça em frangos de corte. In: 38a Reunião Anual da Sociedade Brasileira de Zootecnia; 2001; Piracicaba, São Paulo. Brasil. p.852-53.

Owings WJ, Reynolds DL, Hasiak RJ. Influence of dietary supplementation with Streptococcus faecium M-74 on broiler body weight, feed conversion, carcass characteristics and intestinal microbial colonization. Poultry Science 1990; 69(8):1257-64.

Sartori JR, Pereira KA, Gonçalves JC, Cruz VC, Pezzato AC, Pinheiro DF. Enzima e simbiótico para frangos de corte nos sistemas convencional e alternativo. 2. Rendimento de carcaça, partes e gordura abdominal. Revista Brasileira de Ciência Avícola 2003; 5(Supplement 5): 36.

SAS Institute. SAS (Statistical Analysis System). SAS user's guide: Statistics. SAS Institute Inc., Cary, NC; 2000. 1 CD ROM.

Takahashi SE. Efeito do sistema de criação sobre o desempenho e qualidade da carne de frangos de corte tipo colonial e industrial. [Dissertação]. Botucatu (SP). Universidade Estadual Paulista. 2003, $64 p$.

Tournt JR. Probioticts. In: 35a Reunião da Sociedade Brasileira de Zootecnia; 1999. Botucatu, São Paulo. Brasil. p. 179-99. 